\title{
The Ecosystem Approach in ecological impact assessment: lessons learned from windfarm developments on peatlands in Scotland
}

\section{Highlights}

- Recent wind energy projects in Scotland mostly fail to consider ecosystem-level impacts on peatland

- Projects on peatland illustrate the usefulness of an ecosystem approach to Environmental Impact Assessment

- Defining more meaningful functional management units can improve Environmental Impact Assessment outcomes

- An ecosystem approach could also improve ecosystem services assessments

\begin{abstract}
The Ecosystem Approach introduced in 1994 through the Convention on Biological Diversity, together with related Ecosystem-based Management and Landscape Approaches are frequently called upon to improve ecological impact assessment. Current practice typically does not have such a systems focus and we explore the potential for explicitly adopting an Ecosystem Approach in the Environmental Impact Assessment process using wind energy development on peatland, in Scotland, as a case study. Based on a review of 21 windfarm projects ( $>50 \mathrm{MW}$ ) approved by the Scottish Government we provide an overview of current practice and identify and discuss how the 12 principles of the Ecosystem Approach can help identify options for more appropriate impact assessment. These include defining functional units of analysis that reflect the spatial and temporal linkages of peatland elements through hydrological connections, rather than a focus on individual vegetation types and simple distance buffers. Our conclusions are not limited to peatland and are relevant wherever meaningful functional management units can be defined, including in marine environments. Our results also show that environmental statements for wind energy development in Scotland largely ignore ecosystem services and the people that benefit from them. As for threatened species and other biodiversity features, an Ecosystem Approach is a prerequisite to the meaningful inclusion of ecosystem services in impact assessment.
\end{abstract}

\section{Keywords}

Windfarm; Environmental Impact Assessment; ecosystem services 


\section{Introduction}

Ecological Impact Assessment (EcIA) plays a crucial role in informing decisions on projects with likely impacts on biodiversity and ecosystems, despite its known limitations (Mandelik et al., 2005). Depending on jurisdictions, the focus is often on species presence or habitat quality (Ashworth et al., 2008). Yet there is now a broad consensus that biodiversity goals are best achieved by methods and concepts targeting populations or communities of interacting species, within their ecological systems (Andrello et al. in press; Bradshaw et al. 2014; Malhi et al. 2014; Simberloff 1998; Bowen 1999; Waylen et al. 2014). Furthermore, social impacts are increasingly considered through the ecosystem service framework (Lamarque et al. 2011; Ban et al. 2013; Jacob et al. 2016). This emerging focus on ecosystems is not reflected in current EcIA practice. We explore here the potential for explicitly adopting an Ecosystem Approach in the Environmental Impact Assessment (EIA) process using onshore wind development in Scotland as a case study, a renewable energy technology with much debated sustainability credentials (Warren \& Birnie, 2009).

The Ecosystem Approach (EA) is "a strategy for the integrated management of land, water and living resources that promotes conservation and sustainable use in an equitable way" that was introduced in 1994 by the Convention on Biological Diversity (CBD; CBD, 2004). Table 1 lists the twelve Ecosystem Approach Principles, and illustrates how EcIA could benefit from this strategic and integrated approach. There is overlap with more loosely defined "ecosystem-based management" (e.g. Grumbine 1994, Brunner \& Clark 1997, Lackey 1998, Slocombe 1998, Curtin \& Prellezo 2010) and the "landscape approach" (e.g. Franklin 1993, Lindenmayer et al., 2008, Sayer et al., 2013). As the primary framework for action under the $\mathrm{CBD}$, our analysis is based on those $12 \mathrm{EA}$ principles.

Table 1: The twelve Ecosystem Approach Principles (CBD, 2004) and their relevance to EIA

\begin{tabular}{|c|c|c|}
\hline \multicolumn{2}{|r|}{ Ecosystem Approach Principles } & Relevance to EIA \\
\hline 1 & $\begin{array}{l}\text { The objectives of management of land, water and living } \\
\text { resources are a matter of societal choices. }\end{array}$ & $\begin{array}{l}\text { EIA aim to ensure that the public are given early and } \\
\text { effective opportunities to participate in decision making } \\
\text { procedures, e.g. through consultations and hearings. }\end{array}$ \\
\hline 2 & $\begin{array}{l}\text { Management should be decentralized to the lowest } \\
\text { appropriate level. }\end{array}$ & $\begin{array}{l}\text { EIA are a mechanism for decentralized decision-making, } \\
\text { often used by local planning / permitting authorities. }\end{array}$ \\
\hline 3 & $\begin{array}{l}\text { Ecosystem managers should consider the effects (actual } \\
\text { or potential) of their activities on adjacent and other } \\
\text { ecosystems. }\end{array}$ & $\begin{array}{l}\text { EIA aim to inform decision-makers of the likely significant } \\
\text { effects of their decision, and this includes effects on } \\
\text { adjacent or distant habitats and species. }\end{array}$ \\
\hline 4 & $\begin{array}{l}\text { Recognizing potential gains from management, there is } \\
\text { usually a need to understand and manage the ecosystem } \\
\text { in an economic context. }\end{array}$ & $\begin{array}{l}\text { Actual or potential uses of habitats, or values associated } \\
\text { with them, are important considerations in EIA (including } \\
\text { baselines and mitigation options). In some instances, such }\end{array}$ \\
\hline 5 & $\begin{array}{l}\text { Conservation of ecosystem structure and functioning, in } \\
\text { order to maintain ecosystem services, should be a } \\
\text { priority target of the ecosystem approach. }\end{array}$ & $\begin{array}{l}\text { as in applying IFC PS6, the concept of ecosystem services is } \\
\text { used to assess these uses and values and take them into } \\
\text { account in decision-making. }\end{array}$ \\
\hline 6 & $\begin{array}{l}\text { Ecosystems must be managed within the limits of their } \\
\text { functioning. }\end{array}$ & $\begin{array}{l}\text { EIAs should identify whether ecosystem functioning is } \\
\text { significantly affected. }\end{array}$ \\
\hline 7 & $\begin{array}{l}\text { The Ecosystem Approach should be undertaken at the } \\
\text { appropriate spatial and temporal scale. }\end{array}$ & $\begin{array}{l}\text { Good EIA practice requires a multi-scale approach where } \\
\text { different issues are assessed at their appropriate spatial and } \\
\text { temporal scale. }\end{array}$ \\
\hline 8 & $\begin{array}{l}\text { Recognizing the varying temporal scales and lag-effect } \\
\text { that characterize ecosystem processes, objectives for } \\
\text { ecosystem management should be set for the long term. }\end{array}$ & $\begin{array}{l}\text { EIA are forward-looking, and can take a long-term } \\
\text { perspective if relevant to the project being assessed }\end{array}$ \\
\hline
\end{tabular}




\begin{tabular}{|c|c|c|}
\hline 9 & Management must recognize that change is inevitable. & $\begin{array}{l}\text { EIA recognize that developments will have some level of } \\
\text { impact and expects the developer to put in place mitigation } \\
\text { and restoration plans. } \\
\text { Equally, the EcIA should predict how the site would change } \\
\text { in case the development does not go ahead. }\end{array}$ \\
\hline 10 & $\begin{array}{l}\text { The Ecosystem Approach should seek the appropriate } \\
\text { balance between, and integration of, conservation and } \\
\text { use of biological diversity. }\end{array}$ & $\begin{array}{l}\text { EclA aim to inform decisions about balancing conservation } \\
\text { of biological diversity and projects with likely significant and } \\
\text { negative effects on biological diversity. As such, EclA should } \\
\text { be limited in scope to those aspects of the environment that } \\
\text { are of conservation value and are likely to be significantly } \\
\text { affected. }\end{array}$ \\
\hline 11 & $\begin{array}{l}\text { The Ecosystem Approach should consider all forms of } \\
\text { relevant information, including scientific and indigenous } \\
\text { and local knowledge, innovations and practices. }\end{array}$ & $\begin{array}{l}\text { The scoping stage of EIA seeks information and advice from } \\
\text { statutory and non-statutory organisations and carries out } \\
\text { research of relevant literature, e.g. the likely spatial and } \\
\text { temporal limits of ecological impacts for specific activities } \\
\text { should be justified, where available, by professionally } \\
\text { accredited or published scientific studies. } \\
\text { Developers should use previous examples of good practice } \\
\text { while assessing impacts and designing mitigation and } \\
\text { restoration works. } \\
\text { Individuals can comment on the proposal. }\end{array}$ \\
\hline 12 & $\begin{array}{l}\text { The Ecosystem Approach should involve all relevant } \\
\text { sectors of society and scientific disciplines. }\end{array}$ & $\begin{array}{l}\text { EIA aims to ensure that the public are given early and } \\
\text { effective opportunities to participate in decision making } \\
\text { procedures, e.g. through consultations and hearings. } \\
\text { Relevant organisations, including statutory consultees are } \\
\text { consulted during scoping process. }\end{array}$ \\
\hline
\end{tabular}

\section{Case-study: windfarms in peatland systems}

In Scotland, most windfarms are sited within blanket mire landscapes, partly because the landform and wind characteristics of these landscapes are favorable, but also because such areas are generally less economically productive and located away from human settlements.

Peatlands are complex ecosystems built up of an interconnected mosaic of individual units with characteristic morphology and topography (Ivanov, 1981; Lindsay et al., 1988). SNH (2003) provide a detailed description of Scottish peatlands and its associated flora and fauna. In active peatlands, these units are hydrologically linked and naturally stabilized by physical and hydrological linkages (Minayeva et al., 2016). However, if one or more components of the complex are hydrologically disrupted, the stability can be lost and by a domino effect, hydrological alterations can spread far from the initial impact (Lindsay and Freeman, 2008). Peatlands are therefore ideally suited to applying the EA.

Blanket mire peatlands provide many important ecosystem services (JNCC, 2011; Bonn et al., 2009). For example, while peatlands cover only about $3 \%$ of Earth's surface, they contain at least $25 \%$ of all carbon stored in soils worldwide (Joosten and Clarke, 2002). Peatland also plays an important role in water purification (Martin-Ortega et al., 2014) and provide important cultural services by underpinning the landscape character of the Scottish Highlands (Whitfield et al., 2011). Scotland has $20440 \mathrm{~km}^{2}$ of peat bog (Carey et al., 2008) - $85 \%$ of the UK resource. However, most peatland in the UK is either degrading or recovering with little remaining in a 'near pristine' state (JNCC, 2011).

Three types of peatlands are found in Scotland: blanket bog, raised bog and fens. Only active raised and blanket bogs receive priority European protection under Annex 1 of the EU Habitats Directive (Council 
Directive 92/43/EEC; EC, 1992). In the lowlands, raised bogs occur as domed mounds of peat and are often isolated features within the landscape, whereas in highly oceanic areas, such as the north and west of Britain, peat tends to develop across entire landscapes, such blanket mire cloaking all but the steepest slopes in a mantle of peat ranging in depth from $30 \mathrm{~cm}$ to several metres. The blanket mire landscape is thus an interconnected mosaic of peat-forming systems which function together in a nested, hierarchical way. The overall hierarchy is termed the 'Tope System' (Figures 1 and 2; Minayeva et al., 2016; Lindsay, in press (b)), and includes:

- Macrotopes, ranging from less than 100 ha to large landscape units extending for more than 10,000 ha

- Mesotopes, individual mire units e.g. raised bog

- Microtopes characterised by distinctive surface morphology (e.g. rounded pools, or linear ridges and hollows), representing a set of vegetation and hydrological conditions.

- Nanotopes which are small-scale structures such as hummocks, pools or ridges (Joosten and Clarke, 2002; Lindsay 2010).

Although not immediately evident, there is a tight functional relationship between the small-scale nanotope structures and the functioning of a whole mesotope or even macrotope. The small-scale surface architecture of alternating drier 'hummock' nanotopes and wetter 'hollow' nanotopes plays a crucial feedback role in sustaining peat-forming conditions. During dry climate phases, the hummock nanotopes expand, thereby slowing surface-water losses from the bog, whereas in wetter climate phases the hollow nanotopes expand to provide greater capacity for water storage and surface run-off (Barber 1981). Drainage induces many of the same responses as a shift towards a drier climate (Lindsay et al., 2014b). Drainage also results in substantial long-term subsidence, altering surface gradients and thus inducing yet further drying and subsidence (van der Schaaf, 2000; Lindsay, 2010). The Tope System provides a means of identifying an ecosystem response to an ecosystem impact using smaller scale elements within the hierarchy as signals of change.

The effects that windfarms have on peatland ecosystems can be difficult to observe in a lifetime of a development, but there is already a substantial knowledge base to build upon. Well known short-term effects of drainage include the succession of peat-forming plants requiring wet conditions by vegetation accustomed to dry conditions. The extremely slow movement of water in the system, however, prevents any significant effects of draining from being seen immediately, apart from the drain faces themselves. Lowering of the water-table near the drain is often the only way the effects of drainage are measured (Lindsay et al., 2014b; Holden et al., 2004), but long-term drainage effects include: 1) collapsing and shrinking of the peat immediately adjacent to the drain (primary consolidation); 2) pressure from the newly dry upper layer on the peat underneath which leads to more water being squeezed out and more subsidence of the bog surface (secondary compression); and 3) rapid decomposing of preserved peat material resulting in additional subsidence (oxidative wastage). These processes result in ever-increasing areas of peat being continuously subsided. The same effects can also be caused by the weight of road materials used in floating tracks (Lindsay et al. 2016). As the short-term visible effects are usually very limited, there is a misconception that road construction and associated drainage have limited impact on peatlands. The long-term effects, however, are rarely studied and monitored precisely because they do not fit within the timescales of an EIA. These long-term impacts can, however, be profound (see Figures 3 and 4). 


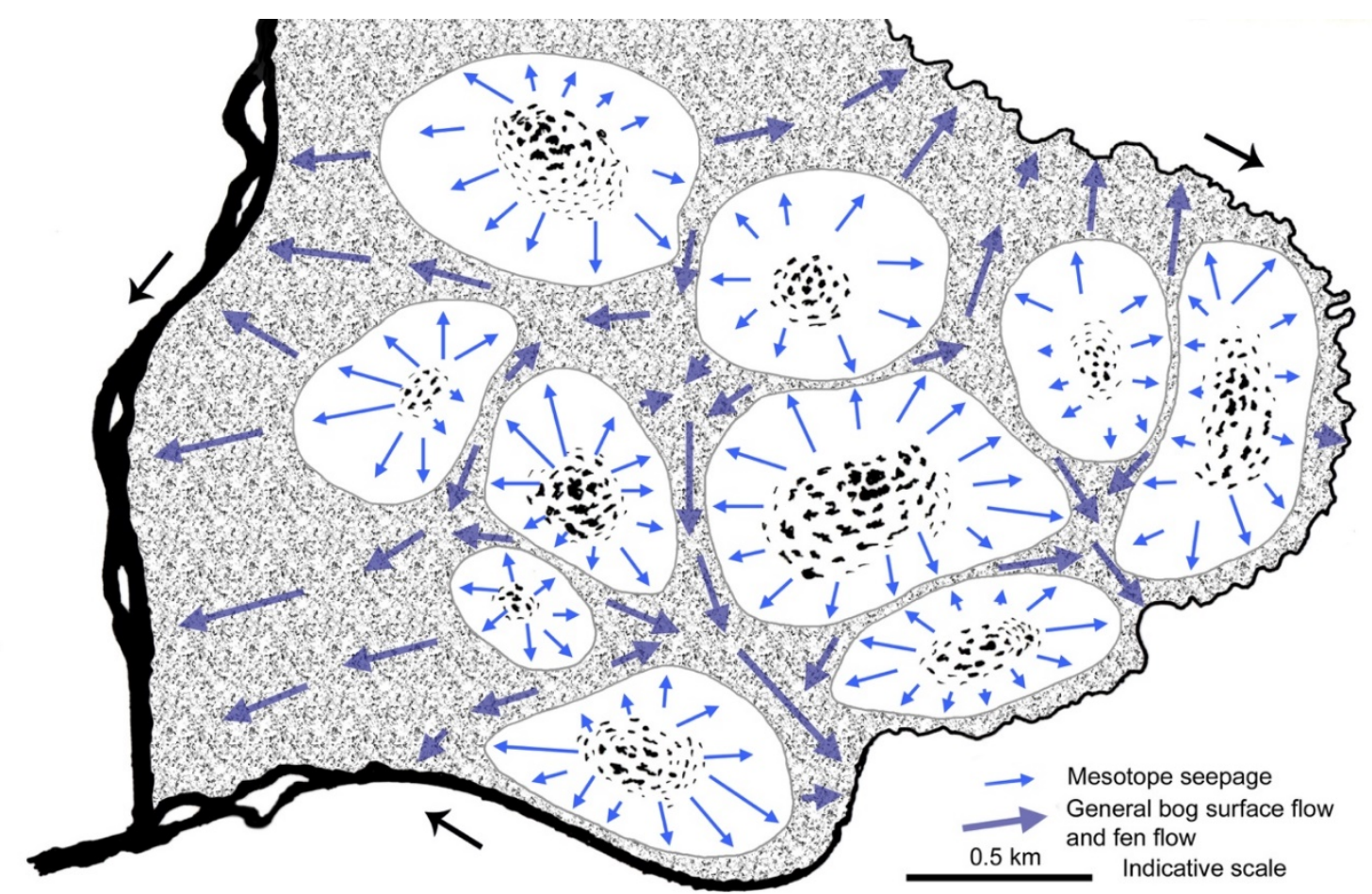

Figure 1. The Tope System - Indicative blanket mire macrotope bounded on all sides by major river systems or streams running on mineral soil. Individual blanket bog units, or bog mesotopes, are white with black shading representing pools or hollows. Seepage from the centre of each bog mesotope is indicated by mid-blue arrows. The wider peat surface, including a range of interconnecting fen mesotopes, is shaded grey. Direction of fen seepage is indicated with purple arrows.

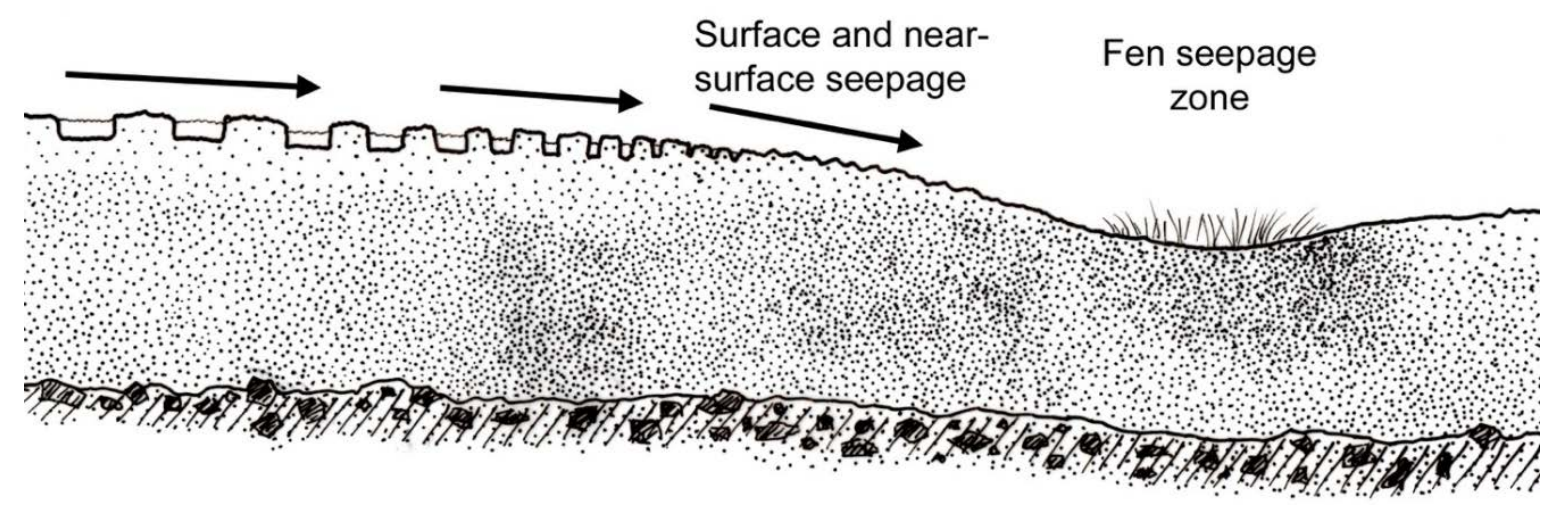

Figure 2. The Tope System - Indicative cross section of a bog mesotope with microtope patterning (left) connecting with a fen mesotope (right) which then connects with an adjacent bog mesotope (right, out of picture). Peat is shown stippled, with stippling indicating the density of peat. Sub-peat glacial till soil is shown by hatching. 


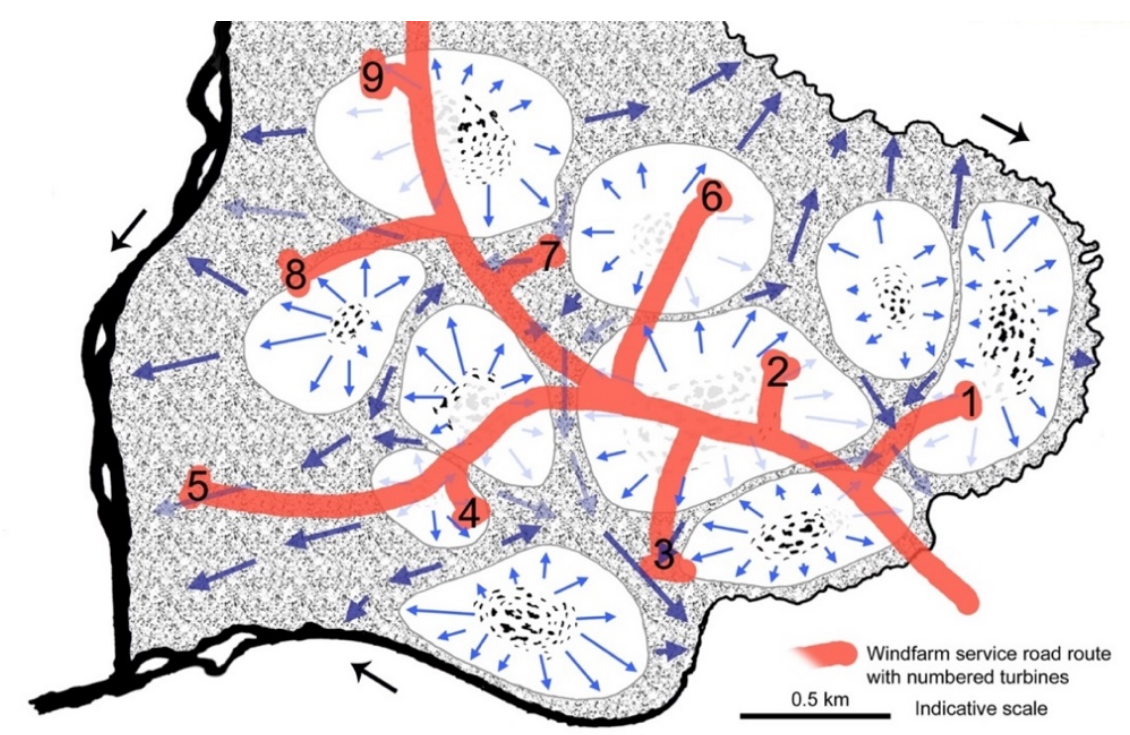

Figure 3. The Tope System and impacts - Indicative long-term impact of a windfarm road (shown in red, with numbered turbines) constructed through the mestopes of the blanket mire ecosystem shown in Figure 1. Mesotope flow lines in both bog and fen systems potentially impacted by the development are shown as faded arrows. Microtope patterns potentially affected within mesotopes are also shown as faded patterning. Note that some mesotopes, and parts of mesotopes, are indicated as being unaffected, although the long-term impacts are difficult to predict.

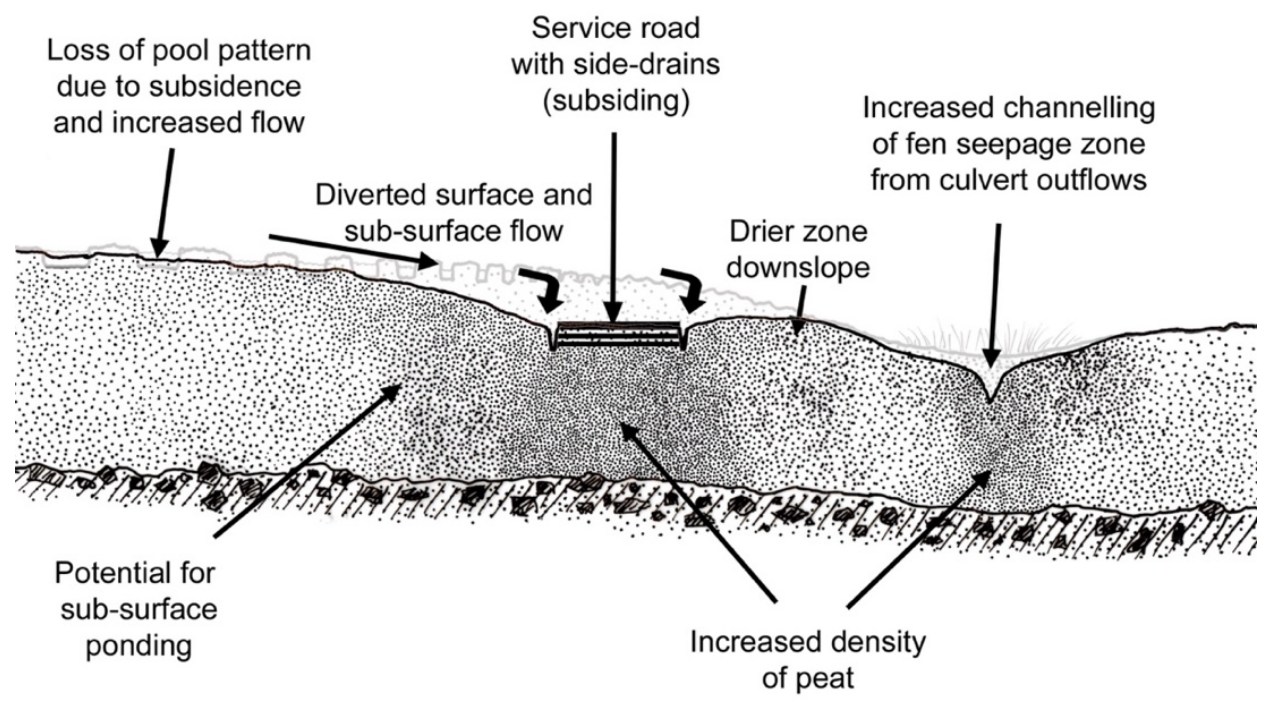

Figure 4. The Tope System and impacts - Cross section of the blanket bog and fen mesotope system shown in Figure 2, but now with a windfarm road constructed through the system in the manner of the road leading to Turbines 4 and 5 in Figure 3 above. Compression and drainage impacts caused by road construction have cause the peat to become denser within the region of the road, while the fen system now receives more focused water inputs from culverts beneath the road, and has itself been channeled to speed water removal from the site. The original level of the peat surface is shown in faint grey. 


\section{Methods}

\subsection{Data}

We reviewed 21 environmental statements of onshore $>50 \mathrm{MW}$ windfarms approved by the Scottish Ministers up to $17^{\text {th }}$ September 2014. The environmental statements and addendums (if applicable) were obtained from the Energy Consents and Deployment Unit, local authorities, companies, Scottish Environment Protection Agency (SEPA), individual persons and the Scottish Government Library. The reviewed environmental statements covered applications submitted by 16 out of 20 developers, and represent $53 \%$ of those approved in that period. Due to limited availability, we reviewed only $37 \%$ (10) of ESs published between 2001 and 2008 but 85\% (11) of those published between 2009 and 2012. Windfarms which were submitted prior to 17th September 2014 but not decided on were not used in this study. Supplementary Material 1 lists all $>50 \mathrm{MW}$ windfarms, their developers and the application year up to $17^{\text {th }}$ September 2014 , and those reviewed here.

Only windfarms for which the complete EIA documentation could be obtained or read were used for this study. The EIA documents included in the review were: Non-technical Summary, introductory chapters (Introduction, EIA, Site Selection, Renewable Energy Planning, and Project Proposal/Description), Nonavian Ecology, Hydrology/Hydrogeology/Geology/Soils/Aquatic Ecology/Surface Water, Recreation and Amenity, and Other Issues chapters. All relevant appendices and addendums were also read. Bull et al. (in press) provides a useful discussion on the issue of availability of such information for policy appraisal.

\subsection{Review package}

In the absence of other peat-related review package, the authors used the knowledge of peatland systems, Lindsay and Freeman's (2008) critical review of the Lewis windfarm environmental statement as well as information provided in guidelines (e.g. SNH, 2013; EC, 1999; IEEM, 2006; SG, 2014), and the Lee et al. (1999) review package to create30 questions (Table 2) that help to assess the peat-related surveys, data provision and impact assessments described in environmental statements. All questions are relevant to the EA principles. Details can be found in the Supplementary Material 2.

A grading system was applied to evaluate the peat-related information provided in the environmental statements. Answers to the review package questions were assessed if they provided: full (1 point), partial (0.5), no information (0) or were not available (N/A). The partial results of the cumulative impact question were split into high (0.75), medium (0.5) and low (0.25) levels to account for separate grading of ecology and hydrology/geology chapters. The grading and results of review questions are provided as Supplementary Material 4.

Some additional data were collected to provide a more in-depth understanding of the current EcIA practices. These included peat depth, vegetation survey methods, the choice of zone of influence, and the justification, levels of impact magnitude.

\section{Results}

The performance of the environmental statements varied greatly (Table 2) depending on specific questions. The review package identified strength and weaknesses across all or most of the statements. 
Developers undertook the required basic surveys, but further investigation showed that the way these surveys were carried out and presented could be significantly improved. The methodologies for assessing magnitude and significance of impacts in peat habitats were clearly defined, but there were some inconsistencies between windfarms about definitions of levels of magnitude of impacts. Although at least some consultants seem to be aware of the hydrological units within peatland systems, none have used them to define the EIA boundary nor to assess peatland structure appropriately. Most windfarms (15 out of 21) carried out a cumulative impact assessment (CIA), but these CIAs all presented minimal content. None of the windfarms identified and assessed impacts on peatland ecosystem services. On the positive side, all developers were aware of the legislation protecting peatland habitats in Scotland and nearly all applicable EIAs (17 out of 18) also carried out peatslide risk assessments. The data supporting the results of this study are available in the Supplementary Material 4, and some specific findings are presented in the next section.

\subsection{Baselines: a focus on vegetation that largely ignores hydrological units}

Only one windfarm mapped hydrological units, i.e. mesotopes. In all other cases peatland boundaries were defined purely by vegetation surveys and peat depth probing (e.g. an area was categorized as a bog only if the peat depth was $>50 \mathrm{~cm}$ ). Vegetation surveys were quite variable. Many developers missed parts of the study area and forested areas were often omitted. Data provision was quite variable and inconsistent between the windfarms. Some used quadrats when carrying out vegetation surveys. Others did not.

Peat depth was measured by all developers, but some EIAs missed parts of infrastructure or other areas while others did not provide maps showing the location of probed depths. Only 52\% of windfarms provided actual peat depth measurements for all peat-probe locations. The remaining environmental statements instead used indicative depths, either because their probes were too short to measure the full depth, or because they chose to present the data in categories (e.g. $0-0.5 \mathrm{~m} ;>0.5-1 \mathrm{~m}$ ) rather than providing actual depths.

Two windfarms identified macrotopes within the extent of their EIA sites, but these were not used to describe the links between different hydrological units. Ninety percent of windfarms identified microtopes within their EIA sites. Most windfarms also sampled individual nanotope zones, although the level of description varied greatly between different projects. It is impossible to determine whether these were the only microtopes and nanotopes present without in-field verification.

The zone of influence for drying out of peat habitats was provided by just eight developments and varied between $10 \mathrm{~m}$ to $50 \mathrm{~m}$. Of these, seven environmental statements supported their decisions with literature or by referring to the environmental statement of another windfarm without any references to guide the reader.

Finally, baseline trends were only included by $43 \%$ of developers, who provided predictions for the management of the peatland habitats on the site in the case where the project did not go ahead. Those who provided partial predictions $(10 \%)$ focused only on the forested areas at their sites. 
Table 2: Percentage of windfarms providing full (Yes) or no (No) information, information provided 'Partially' or information N/A. The percentages were rounded up to the nearest number so the total sum for few questions exceeds $100 \%$. $\mathrm{N}=21$.

\begin{tabular}{|c|c|c|c|c|}
\hline \multirow{2}{*}{$\begin{array}{l}\text { REVIEW PACKAGE QUESTIONS } \\
\text { Basic information }\end{array}$} & \multicolumn{4}{|c|}{$\begin{array}{l}\text { \% OF WINDFARMS PROVIDING } \\
\text { INFORMATION }\end{array}$} \\
\hline & Yes & Partially & No & N/A \\
\hline Was there a reference to UKBAP/EC Habitats Directive* Annex 1 list? & 100 & & & \\
\hline Were peat, bog or peatlands defined? & 67 & & 33 & \\
\hline Was peatslide risk assessment carried out and included in the ES? & 81 & & 5 & 14 \\
\hline Was carbon calculator used in the EIA? & 67 & & 24 & 9 \\
\hline Hydrological system & Yes & Partially & No & N/A \\
\hline Was peat depth measured? & 95 & 5 & & \\
\hline $\begin{array}{l}\text { Was peat depth sampled across the EIA site and along the proposed } \\
\text { infrastructure? }\end{array}$ & 24 & 57 & 19 & \\
\hline Was actual peat depth provided for all samples? & 52 & 19 & 29 & \\
\hline Were mesotopes and their margins identified and mapped? & 5 & 24 & 71 & \\
\hline Were links between various hydrological unit levels described? & & 5 & 95 & \\
\hline Were macrotopes and their margins identified and mapped? & & 10 & 90 & \\
\hline $\begin{array}{l}\text { Were macrotope boundaries used to identify the geographical area of EIA } \\
\text { assessment? }\end{array}$ & & & 100 & \\
\hline Vegetation & Yes & Partially & No & N/A \\
\hline Were Phase 1 and NVC used to survey habitats? & 90 & 10 & & \\
\hline Were samples taken evenly from across the entire range of the study area? & 29 & 71 & & \\
\hline Was raw data provided for all NVC quadrats? & 57 & 5 & 38 & \\
\hline Were microtope / vegetation patterns across each mesotope identified? & 90 & & 10 & \\
\hline $\begin{array}{l}\text { Were individual nanotope zones within each microtope / vegetation stand } \\
\text { sampled? }\end{array}$ & 5 & 57 & 29 & 10 \\
\hline Were fen types classified? & 71 & 19 & 5 & 5 \\
\hline Was the timing and duration of surveys stated? & 43 & 52 & 5 & \\
\hline Habitats & Yes & Partially & No & N/A \\
\hline Were areas (ha) given for each vegetation community or mesotope? & 67 & & 33 & \\
\hline Was land management of the development site identified? & 100 & & & \\
\hline $\begin{array}{l}\text { Was the management of peatland habitats on the site described in case the } \\
\text { project was not to go ahead? }\end{array}$ & 43 & 10 & 48 & \\
\hline $\begin{array}{l}\text { Was the level of peat habitat condition assessed (e.g. recovering/re- } \\
\text { vegetative, stable, deteriorating/drying out)? }\end{array}$ & 19 & 67 & 14 & \\
\hline Identification and assessment of impacts on peat & Yes & Partially & No & $\mathrm{N} / \mathrm{A}$ \\
\hline Was magnitude of impacts on peat habitats described? & 95 & 5 & & \\
\hline Was significance of impact on peat habitats described? & 100 & & & \\
\hline $\begin{array}{l}\text { Were uncertainties, information gaps and/or limitations of the study } \\
\text { explained? }\end{array}$ & 86 & & 14 & \\
\hline Were direct impacts on peat habitats described and quantified? & 76 & 19 & 5 & \\
\hline Were indirect impacts on peat habitats identified and assessed? & 38 & 57 & 5 & \\
\hline $\begin{array}{l}\text { Were impacts on ecosystem services of peatland habitats identified and } \\
\text { assessed? }\end{array}$ & & & 100 & \\
\hline $\begin{array}{l}\text { Was zone of influence used for assessment of indirect impacts (doesn't include } \\
\text { peatslide)? }\end{array}$ & 38 & & 62 & \\
\hline Were cumulative effects on peat habitats identified and assessed? & & $\begin{array}{c}14 \text { (high), } \\
29 \text { (medium), } \\
29 \text { (low) }\end{array}$ & 29 & \\
\hline
\end{tabular}

*EC Habitats Directive refers to Council Directive 92/43/EEC (EC, 1992). 


\subsection{Impact assessment: lack of standards impedes cross-study comparisons and CIA}

Direct habitat loss calculations could be found in thirteen environmental statements. By looking at the dimensions of turbine bases, access tracks, crane hard standings, compounds, substations and borrow pits, some variability can be observed. The buffers used to calculate the habitat loss ranged from 0 to $40 \mathrm{~m}$, although some statements included only the habitat-take per structure rather than specifying dimensions. Of the thirteen statements that specified the habitat-loss dimensions for roads, only two mentioned space for cabling and only three developments stated additional loss for widening locations (e.g. bends, junctions).

The magnitude of impacts was defined in various ways including: by changes in integrity, in hydrological condition, or hydrological and hydrogeological regime, in habitat loss/disturbance thresholds, or by considering various other factors. Windfarms often used various methods, sometimes for different chapters within the same Statement. For example, the threshold used to define high magnitude of habitat loss/disturbance varied greatly: $>20 \%$ (Moy, Stornoway, Galawhistle and Dorenell); $20-80 \%$ (Wester Dod); $>10 \%$ (Beinneun); 10-50\% (Rothes); and >50\% (Harburnhead and Bhlaraidh). Beinneun used a much lower threshold for defining high magnitude in its ecological chapter ( $>10 \%$ of habitat loss) than in the geology chapter $(>50 \%$ of total loss of a geological receptor or peat habitat site). The remaining magnitude levels also varied accordingly.

Fourteen environmental statements either did not assess the cumulative impacts on habitats at all or their assessment was restricted to one or two sentences which did not actually provide useful information. Of the remaining statements, three calculated habitat loss, but only one development calculated direct and indirect losses separately. Two developments considered habitat loss but did not calculate it. Of these, one mentioned that it was unable to evaluate effects on habitats as other windfarms used different methodologies to assess effects on habitats. Instead of calculating losses they assessed them qualitatively by looking at what types of habitats had the highest cumulative loss and what cumulative habitat gains would be achieved by carrying out habitat restorations outlined in habitat management plans. Another statement looked at proposed developments but omitted constructed developments or those under construction. One development did not assess cumulative habitat loss because it did not predict any significant habitat loss within their windfarm and the developer considered the habitats they affect as widespread.

The methods used for CIA on hydrology and geology also varied between developments. Four developments did not mention CIA at all, while three others gave statements which do not qualify as assessments. The distance for considering impacts varied greatly: $1.5 \mathrm{~km}$ from the development boundary; or $10 \mathrm{~km}, 15 \mathrm{~km}$ and $60 \mathrm{~km}$ radiuses. Some projects looked only at windfarms. Others included various types of developments such as a pumped storage scheme and a surface coal mine. Considered impacts included: changes to flow rates; pollution; flooding; surface and groundwater quality; freshwater ecology, private water supply; and sedimentation. 


\section{Discussion - Lessons learned from windfarm developments in Scotland}

For the past 17 years Scottish EcIA guidelines (IEEM 2006, CIEEM 2016) have been advising that significant effects are related to impacts on structure and function of defined sites, habitats or ecosystems and the conservation status of habitats and species. Logically, the EA could help with the successful implementation of an impact assessment emphasizing the structure and functionality of systems. In fact, the Scottish Government has published documents that promote the application of Ecosystem Approach within decision-making processes which affect land use since 2011 (Natural Scotland 2011, 2012; SG 2016). This review, however, has revealed that there is enormous variability in the methods used to survey sites, present data and assess impacts.

Despite some positive aspects, such as good policy coverage and widespread peat probing, vegetation surveys and peatslide risk assessments, our review shows scope for major improvement. The assessment of the structure of peatland systems at the sites was generally limited and did not inform the chosen spatial extent of the EIA. This was especially evident where the edge of the EIA site cut across hydrologically linked units (i.e. mesotopes or macrotopes). The definition of the site/ecosystem integrity was used without any real understanding of the concept or how it could be measured. Other limitations included indirect and cumulative impact assessments that rarely provided quantitative evidence and differences in methodologies used to calculate direct impacts. Supplementary Material 3 provides a discussion on how this reflects on the potential use of the EA in EcIA, with the overview provided below.

Specific principles that are generally poorly covered and could benefit from the EA include: considering effects on adjacent ecosystems (Principle 3); conserving ecosystem structure and functioning for ecosystem services provision (Principle 5); managing ecosystems within the limits of their functioning (Principles 6); considering appropriate spatial and temporal scales (Principle 7); recognising time-lags (Principle 8); and seeking an appropriate balance between, and integration of, conservation and use of biological diversity (Principle 10). These translate to specific responsibilities of the EcIA including: identification and assessment of the peatland system, and the assessment of both indirect and cumulative impacts (CIA).

\subsection{Identification and assessment of functional ecological units}

The functional extent of a peatland system is not currently taken into consideration within the EcIAs of windfarms, including the impact assessment and the mitigation and restoration stages. In fact, none of the reviewed environmental statements identified and mapped the boundaries of macrotopes or mesotopes. This, together with the failings of CIA, make it a challenge to assess whether a given peat system may suffer widespread impact, or even catastrophic failure, because of development decisions.

Despite the IEEM (2006) and CIEEM's (2016) recommendation to take into consideration impacts on structure and functioning of ecosystems when identifying significant effects, current field assessments are insufficient to build an adequate picture of the structure of peatland ecosystems and identify limits to its functioning. The currently-used combination of vegetation surveys and peat depth probing does not result in truthful representation of the peatland body. Macrotopes and mesotopes will most likely consist of several habitats defined by the National Vegetation Classification (NVC; Rodwell, 2006) of which the majority might not be legally protected. Although not classified as peatlands due to their depths lower 
than $50 \mathrm{~cm}$, shallow peat and podzol soils might also form part of a macrotope as the depth of peat is irregular across blanket bogs.

Following Ecosystem Approach Principles (3, 5, 6 and 7), peat units should be integrated into the definition of EcIA study areas, as the boundaries of a macrotope represent the limits of the system's functioning and everything within these boundaries is connected hydrologically (Minayeva et al., 2016). Instead of focusing on individual habitats defined largely by vegetation, there is a need for an approach shift to focus on understanding of the system structure. Application of the Tope System is relatively straightforward. First there is the desk study, where maps and aerial photographs are used to identify provisional macrotope, mesotope and microtope boundaries. Having identified these provisional boundaries, field survey then confirms the validity of the macrotope boundaries (i.e. that the boundary marks the edge of the peat). Field survey also allows the characterisation of mesotope and microtope units, the latter on the basis of nanotope and vegetation composition. None of these steps differs radically from what is already done as part of an EIA investigation, but it would ensure that the work is undertaken comprehensively and within a logical, structured framework.

Considering the EA Principles (7,8), adopting the Tope System within an EcIA would make it easier to choose appropriate spatial scales and would allow more meaningful predictions of the potential long-term extent and nature of likely impacts. On the other hand, the issue of temporal scale could not perhaps be demonstrated within the context of an EIA as it requires long-term studies beyond the life of the development. However, these potential long-term effects should be clearly explained in the environmental statement and much greater emphasis should be placed on indicating the probability of such effects. This, then, could be considered in cumulative impact assessments and strategic environmental assessments of energy or land-use policies that favor wind energy development on peatland.

\subsection{Opportunities for comparable impact assessment methodologies}

Our study has shown that there is considerable variability in e.g. thresholds for magnitude levels for percentage of lost habitats, quantitative methods of impact assessments, habitat loss dimensions, etc. CIEEM's 2016 guidelines provide a template for writing the EcIA's chapters which should add some consistency in presenting information across environmental statements. However, to be able to seek an appropriate balance between, and integration of, conservation and use of biological diversity (Ecosystem Approach Principle 10) there is an urgent need for standardised assessment methods, e.g. to determine habitat loss and disturbance, and their significance. Structured methodologies which produce comparable data should be developed and disseminated to facilitate comparisons and learning from project to project, as has been done for other wetland types in the USA (Fennessy et al. 2007) or more recently in France (Gaucherand et al. 2015; Gayet et al. in press.). The EA can help to clarify the meaning of the zone of influence, which is currently open to interpretation.

\subsection{Assessment of cumulative impacts}

The CIAs analysed in this study were generally of poor quality or even absent. Where present, they lacked any useful information or results were based mainly on descriptive and qualitative assessments, which mirrors findings of previous studies (e.g. Cooper and Sheate, 2002; Byron et al., 2000; Pope et al. 2013). The use of arbitrary boundaries for EcIAs and insufficient studies of the peatland structure make it unlikely that the entire affected peatland ecosystem, and adjacent ecosystems, were assessed through the 
CIA or indirect impact assessment. Incorporating the hydrological peat units approach would strengthen the assessments' information base and could help specify which other developments are within the boundary of current, adjacent and other ecosystems and should be assessed by the CIA.

CIEEM's 2016 guidelines are required to bring EcIA in Scotland to the same level as the Scottish Government's Land Use Strategy (SG, 2016) which specifies that "land use decisions should be informed by an understanding of the functioning of the ecosystems which they affect in order to maintain the benefits of the ecosystem services which they provide" (p. 12). All ESs should now recognise where development's ecological effects could affect the provision of ecosystem services.

\subsection{Ecosystem services}

The "ecosystem perspective" (Grumbine, 1994) we advocate here would help to understand the functionality of the system, and therefore also ecosystem service provision. Although they are increasingly referred to in the context of foreign investment decisions in developing country contexts (e.g. following Performance Standard 6 of the International Finance Corporation), ecosystem services are still to be integrated into the EcIA in many jurisdictions, including Scotland. Our results show that recent environmental statements of windfarms in Scotland largely ignore ecosystem services and the people that benefit from them, though their inclusion could allow for cost-benefit analysis to be applied using robust scientific evidence.

Ecosystem services can usefully inform development decisions (Baker et al. 2013, Bull et al. 2016, Jacob et al. 2016). Their use could foster a more integrated understanding of the interlinkages between different themes or topics currently treated separately by developers and EIA practitioners, as recommended by the EA. This is particularly true of the environmental and social dimensions of impact assessment (Rosa \& Sanchez 2016). However, a focus on ecosystem services does not automatically translate into an "ecosystem perspective" (Grumbine, 1994). Zawadzka et al. (2017) provide an example of ecosystemservice based EIA for a linear infrastructure project in the UK, but it fails to incorporate the underlying ecosystem functioning by focusing exclusively on broadly defined land-cover categories (Lavorel et al. 2017). Therefore, we conclude that an EA is necessary (but insufficient) for the inclusion of ecosystem services in impact assessment.

\section{Conclusions}

Our review identifies several gaps and limitations in recent assessments of the impacts of wind energy development on peatland in Scotland. In practice, little holistic consideration is given to the peat system and its hydrological interconnections, and inconsistent approaches are used to assess impacts, particularly indirect, long-term and cumulative impacts. Vegetation, surface morphology, hydrology, slope stability and water quality are too often considered in isolation rather than as mutually linked indicators of condition, function and, ultimately, ecosystem services. Active adoption of the EA approach by the windfarm industry is required if this highly compartmentalized and fundamentally unhelpful approach is to evolve into a more informative and meaningful system of assessment. Wind energy development on peatland offers a good illustration of the usefulness of an EA to impact assessment more generally. Windfarm development on peat is not an issue restricted to Scotland, nor just to the UK. There are similar developments in most parts of the world where peatland systems, but particularly blanket mires, are both attractive to windfarm developers and currently offer few alternative financial benefits to landowners 
(Lindsay, in press (a)). Furthermore, one of the main impacts of windfarms on the peatland ecosystem is drainage, which is an extremely common activity carried out more widely on peatland systems throughout the world. The Tope System provides an integrated descriptor for the entire functional entity of the peat system and can as easily assess the potential impacts of such drainage and its cumulative effects as it can on the impacts of a windfarm development. This more widely applicable improvement in the way that peatland impact assessments are undertaken is why we recommend an ecosystem approach, based on the Tope System, to the assessment of development projects on peatland.

Indeed, our conclusions are not limited to peatland ecosystems. Incorporating the ecosystem approach into impact assessment is possible wherever meaningful functional management units can be defined, including in marine environments. This is already a requirement for projects with possible impacts on threatened species and habitats seeking financing from International Finance Corporation (IFC) or other financial institutions that apply similar performance standards (Rainey et al. 2015). IFC's Performance Standard 6 requires that developers define ecologically appropriate areas of analysis ("discrete management units" of "critical habitat") to ensure impacts are adequately assessed. Here also, simple vegetation mapping is often insufficient and more integrative approaches that consider multiple interacting elements of structure and functioning of an ecosystem are often needed to make robust assessments of impacts and their significance (Thompson et al. 1997).

Shifting to an ecosystem approach in EIA would require a step change. It will be challenging as any innovation in EIA practice must conform to existing legislation (which is focused on a limited list of protected features rather than ecosystems and their inherent complexity) and needs supporting methods to be developed and agreed upon by a broad community of practitioners (and standardization carries its own risks), as well as targeted capacity building. This can be costly, and generate resistance from developers in the short-term, but if assessment systems were set in place by legislators and adopted as best practice by those responsible for undertaking impact assessments, developers would then be able to approach any given development proposal with foreknowledge of the tasks required and costs involved, and thus make an informed judgement about the commercial viability of a proposed scheme. In the longer term, agreed standards can foster comparability and shared learning, and an ecosystem approach to EIA could provide more meaningful outcomes, ultimately leading to better-informed decision-making and generating support for effective environmental management in the context of development. This is the shared ambition of the EA and EIA.

\section{Acknowledgements}

BLINDED 


\section{Supplementary Material}

- Supplementary Material 1: List of windfarms

- Supplementary Material 2: Review package questions with justifications for using them.

- Supplementary Material 3: Synthesis of lessons learned from windfarm developments in Scotland for each Ecosystem Approach Principle.

- Supplementary Material 4: Review package grading and results

\section{References}

Andrello M., Devaux C., Quétier F. \& Till-Bottraud I., in press. Paying for conservation: a bioeconomic analysis of land use effects on the viability of an endangered species, Eryngium alpinum L. Journal of Applied Ecology, in press.

Ashworth, P., Bolton, S., Edwards, R., Mole, Al., Somper, C. and Weldon, S., 2008. Case study to develop tools and methodologies to deliver an ecosystem approach - Heysham to M6 Link. DEFRA Research Project NR0110, DEFRA, London, UK.

Baker, J., Sheate, W. R., Phillips, P., \& Eales, R., 2013. Ecosystem services in environmental assessment - help or hindrance? Environmental Impact Assessment Review, 40, pp. 3-13. DOI: 10.1016/j.eiar.2012.11.004

Ban, N.C., Mills, M., Tam, J., Hicks, C.C., Klain, S., Stoeckl, N., Bottrill, M.C., Levine, J., Pressey, R.L., Satterfield, T. and Chan, K., 2013. A social-ecological approach to conservation planning: embedding social considerations. Frontiers in Ecology and the Environment, 11(4), p.194-202. DOI: $10.1890 / 110205$

Barber, K.E., 1981. Peat Stratigraphy and Climate Change: A palaeoecological test of the theory of cyclic peat bog vegetation. A.A.Balkema, Rotterdam, The Netherlands.

Bonn, A., Holden, J., Parnell, M., Worrall, F., Chapman, P.J., Evans, C.D., Termansen, M., BeharryBorg, N., Acreman, M.C., Rowe, E., Emmett, B. and Tsuchiya, A., 2009. Ecosystem services of peat - Phase 1 - Project code: SP0572. DEFRA, London, UK.

Bowen, B.W., 1999. Preserving genes, species, or ecosystems? Healing the fractured foundations of conservation policy. Molecular ecology, 8(s1), DOI: 10.1046/j.1365-294X.1999.00798.x.

Bradshaw, C., Kapustka, L., Barnthouse, L., Brown, J., Ciffroy, P., Forbes, V., Geras'kin, S., Kautsky, U. \& Bréchignac, F., 2014. Using an Ecosystem Approach to complement protection schemes based on organism-level endpoints. Journal of environmental radioactivity, 136, p. 98-104, DOI: 10.1016/j.jenvrad.2014.05.017.

Brunner, R.D. and Clark, T.W., 1997. A practice- based approach to ecosystem management. Conservation biology, 11(1), pp.48-58, DOI: 10.1046/j.1523-1739.1997.96005.x.

Bull, J.W., Jobstvogt, N., Böhnke-Henrichs, A., Mascarenhas, A., Sitas, N., Baulcomb, C., Lambini, C.K., Rawlins, M., Baral, H., Zähringer, J. and Carter-Silk, E., 2016. Strengths, weaknesses, opportunities and threats: A SWOT analysis of the ecosystem services framework. Ecosystem services, 17, pp.99-111.

Bull J.W., Brauneder K., Darbi M., van Teeffelen A.J.A., Quétier F., Brooks S., Dunnett S., Strange N., in press. Data transparency regarding the implementation of European 'no net loss' biodiversity policies. Biological Conservation, in press.

Byron, H.J., Treweek, J.R., Sheate, W.R. and Thompson, S., 2000. Road Developments in the UK: An Analysis of Ecological Assessment in Environmental Impact Statements Produces between 1993 
and 1997. Journal of Environmental Planning and Management, 43(1), p.71-97, DOI: 10.1080/09640560010775.

Carey, P.D., Wallis, S., Chamberlain, P.M., Cooper, A., Emmett, B.A., Maskell, L.C., McCann, T., Murphy, J., Norton, L.R., Reynolds, B., Scott, W.A., Simpson, I.C., Smart, S.M. andUllyett, J.M., 2008. Countryside Survey: UK Results from 2007. NERC/Centre for Ecology \& Hydrology, p. 105.

CBD, 2004. CBD Guidelines. The Ecosystem Approach. Secretariat of the Convention on Biological Diversity, Montréal, Canada.

CIEEM, 2016. Guidelines for Ecological Impact Assessment in the UK and Ireland: Terrestrial, Freshwater and Coastal, 2nd edition. Chartered Institute of Ecology and Environmental Management, Winchester

Cooper, L.M. and Sheate, W.R., 2002. Cumulative effects assessment: A review of UK environmental impact statements. Environmental Impact Assessment Review, 22, p.415-439, DOI: 10.1016/S01959255(02)00010-0.

Curtin, R. and Prellezo, R., 2010. Understanding marine ecosystem based management: a literature review. Marine Policy, 34(5), pp.821-830, DOI: 10.1016/j.marpol.2010.01.003

European Commission, 1992. Council Directive 92/43/EEC of 21 May 1992 on the conservation of natural habitats and of wild fauna and flora. Official Journal of the European Communities.

EC, 1999. Guidelines for the Assessment of Indirect and Cumulative Impacts as well as Impact Interactions. Luxemburg: Office for Official Publications of the European Communities.

EC, 2007. Interpretation Manual of European Union Habitats. EUR 27. Nature and Biodiversity. European Commission, Brussels, Belgium

Fennessy, M.S., Jacobs, A.D., Kentula, M.E., 2007. An evaluation of rapid methods for assessing the ecological condition of wetlands. Wetlands, 27, pp. 543-560.

Franklin, J.F., 1993. Preserving biodiversity: species, ecosystems, or landscapes? Ecological applications, 3(2), p.202-205, DOI:10.2307/1941820.

Gaucherand, S., Schwoertzig, E., Clément, J.C., Johnson, B. and Quétier F., 2015. The cultural dimensions of freshwater wetland assessments: lessons learned from the application of US rapid assessment methods in France. Environmental Management 56(1), p.245-259.

Gayet G., Baptist F., Fossey M., Caessteker P., Clément J.C., Gaillard J., Gaucherand S., IsselinNondedeu, F., Poinsot C. \& Quétier F., 2018. Wetland assessment in France: lessons learned from the development, validation and application of a new functions based method. In Dorney J., Savage R., Tiner R. \& Adamus P. (Eds): Wetland and Stream Rapid Assessments: Development, Validation, and Application, Elsevier, in press.

Grumbine R.E. 1994. What is ecosystem management? Conservation Biology, 8(1), p. 27-38, DOI: 10.1046/j.1523-1739.1994.08010027.x.

Holden, J., Chapman, P.J. and Labadz, J.C., 2004. Artificial drainage of peatlands: hydrological and hydrochemical process and wetland restoration. Progress in Physical Geography, 28(1). p.95-123, DOI: 10.1191/0309133304pp403ra.

IEEM, 2006. Guidelines for ecological impact assessment in the United Kingdom, Institute of Ecology and Environmental Management, London, UK.

Jacob, C., Vaissière, A.C., Bas, A., Calvet, C., 2016. Investigating the inclusion of ecosystem services in biodiversity offsetting. Ecosystem Services, 21, p. 92-102, DOI: 10.1016/j.ecoser.2016.07.010. 
JNCC, 2011. Towards an assessment of the state of UK Peatlands, JNCC report No. 445. Joint Nature Conservation Committee, London, UK.

Joosten, H. and Clarke, D. 2002. Wise Use of Mires and Peatlands - Background and Principles Including a Framework for Decision-making. International Mire Conservation Group and International Peat Society. NHBS, Totnes, Devon.

Lackey, R.T., 1998. Seven pillars of ecosystem management. Landscape and urban planning, 40(1), p.21-30, DOI: 10.1016/S0169-2046(97)00095-9.

Lamarque, P., Quétier, F. and Lavorel, S. (2011): The diversity of the ecosystem services concept: implications for quantifying the value of biodiversity to society. Compte Rendus Biologies 334(56), p. 441-449.

Lavorel, S., Bayer, A., Bondeau, A., Lautenbach, S., Ruiz-Frau, A., Schulp, N., Seppelt, R., Verburg, P., van Teeffelen, A., Vannier, C. and Arneth, A., 2017. Pathways to bridge the biophysical realism gap in ecosystem services mapping approaches. Ecological Indicators, 74, pp.241-260.

Lee, N., Colley, R., Bonde, J. and Simpson, J., 1999. Reviewing the quality of environmental statements and environmental appraisals. EIA Centre, Department of Planning and Landscape, University of Manchester, Occasional Paper, 55, p.1-72.

Lindenmayer, D., Hobbs, R.J., Montague- Drake, R., Alexandra, J., Bennett, A., Burgman, M., Cale, P., Calhoun, A., Cramer, V., Cullen, P. and Driscoll, D., 2008. A checklist for ecological management of landscapes for conservation. Ecology letters, 11(1), p.78-91, DOI: 10.1111/j.14610248.2007.01114.x.

Lindsay, R., 2010. Peatbogs and Carbon: a critical synthesis. RSPB, Sandy, UK.

Lindsay, R., in press (a). Peatlands and Windfarms: Conflicting Carbon Targets and Environmental Impacts. In: C.M. Finlayson, G.R. Milton, R.C. Prentice and N.C. Davidson (eds.) The Wetland Book II: Distribution, Description and Conservation. pp. 1-13. Netherlands: Springer Nature.

Lindsay, R., in press (b). Peatland (Mire Types): Based on Origin and Behavior of Water, Peat Genesis, Landscape Position, and Climate. In: C.M. Finlayson, G.R. Milton, R.C. Prentice and N.C. Davidson (eds.) The Wetland Book II: Distribution, Description and Conservation. pp. 1-23. Netherlands: Springer Nature.

Lindsay, R. and Bragg, O., 2005. Windfarms and blanket peat. A report on the Derrybrien bog slide. Second edition. Sustainability Research Institute, University of East London and the Derrybrien Development Cooperative Ltd.

Lindsay, R. and Freeman, J., 2008. Lewis Wind Power (LWP) Environmental Impact Statements (EIS) 2004 and 2006 - A Critical Review. Sustainability Research Institute, University of East London.

Lindsay, R., Birnie, R. and Clough, J., 2014a. IUCN UK Committee Peatland Programme Briefing Note No.2. Peat Bog Ecosystems: Structure, Form, State and Condition.

Lindsay, R., Birnie, R. and Clough, J., 2014b. IUCN UK Committee Peatland Programme Briefing Note No.3. Impacts of Artificial Drainage on Peatlands.

Lindsay, R., Birnie, R. and Clough, J., 2016. IUCN UK Committee Peatland Programme Briefing Note No. 12. Tracks across peatlands.

Malhi, Y., Gardner, T.A., Goldsmith, G.R., Silman, M.R. and Zelazowski, P., 2014. Tropical forests in the Anthropocene. Annual Review of Environment and Resources, 39, p.125-159, DOI: 10.1146/annurev-environ-030713-155141. 
Mandelik, Y., Dayan, T. \& Feitelson, E., 2005. Planning for biodiversity: the role of Ecological Impact Assessment. Conservation Biology, 19(4), p.1254-1261, DOI: 10.1111/j.1523-1739.2005.00079.x.

Martin-Ortega, J., T. E. H. Allott, K. Glenk, and M. Schaafsma. 2014. Valuing water quality improvements from peatland restoration: Evidence and challenges. Ecosystem Services 9:34-43, DOI: $10.1016 /$ j.ecoser.2014.06.007.

Millon, L., Julien, J.F., Julliard, R. and Kerbiriou, C., 2015. Bat activity in intensively farmed landscapes with wind turbines and offset measures. Ecological Engineering, 75, p. 250-257, DOI: 10.1016/j.ecoleng.2014.11.050.

Minayeva, T. Yu., Bragg, O.M. and Sirin, A.A. Towards ecosystem-based restoration of peatland biodiversity. Mires and Peat, 19, Article 01, p.1-36, DOI: 10.19189/MaP.2013.OMB.150.

Natural Scotland, 2011. Applying an ecosystems approach to land use. Information Note.

Natural Scotland, 2012. Making the most of communities' natural assets: green infrastructure.

Pope, J., Bond, A., Morrison-Saunders, A. and Retief, F., 2013. Advancing the theory and practice of impact assessment: Setting the research agenda. Environmental Impact Assessment Review, 41, p.19, DOI: 10.1016/j.eiar.2013.01.008.

Rainey, H.J., Pollard, E.H.B., Dutson, G., Ekstrom, J.M.M., Livingstone, S.R., Temple, H.J. \& Pilgrim, J.D., 2014. A review of corporate goals of No Net Loss and Net Positive Impact on biodiversity. Oryx, 49(2), pp. 232-238.

Rodwell, J., 2006. National Vegetation Classification: Users' Handbook. Joint Nature Conservation Committee, London, UK.

Rosa, J. C. S., Sánchez, L. E., 2016. Advances and challenges of incorporating ecosystem services into impact assessment. Journal of environmental management, 180, pp. 485-492.

Sayer, J., Sunderland, T., Ghazoul, J., Pfund, J.L., Sheil, D., Meijaard, E., Venter, M., Boedhihartono, A.K., Day, M., Garcia, C. and van Oosten, C., 2013. Ten principles for a landscape approach to reconciling agriculture, conservation, and other competing land uses. Proceedings of the National Academy of Sciences, 110(21), p.8349-8356, DOI: 10.1073/pnas.1210595110.

van der Schaaf, S., 2000. Subsidence along disturbed bog margins and its expansion into bogs. In: International Peat Society, Proceedings of the $11^{\text {th }}$ International Peat Congress: Sustaining our Peatlands. 2000. Quebec: Canadian Society of Peat and Peatlands, p.262-268.

Scottish Renewables, 2016. Renewables in Numbers. [Online] Available at: https://www.scottishrenewables.com/sectors/renewables-in-numbers/ [Accessed 07/05/17].

Scottish Government, 2002. Electricity. 2002 No.163. The Renewables Obligation (Scotland) Order 2002. Scottish Statutory Instruments.

Scottish Government, 2013. Electricity Generation Policy Statement.

Scottish Government, 2016. Getting the best from our land. A Land Use Strategy for Scotland 2016 2021.

Scottish Government, 2014. Guidance on Developments on Peatland - Site Surveys. [Online] Available at: http://www.gov.scot/Topics/Business-Industry/Energy/Energy-sources/19185/178521/CSavings/PSG2011 [Accessed 17/11/2014].

SNH, 2003. Scotland's Living Landscapes - Boglands. Scottish Natural Heritage, Edinburgh, UK. www.snh.org.uk/pdfs/publications/livinglandscapes/boglands.pdf 
SNH, 2009. Policy Statement. Strategic locational guidance for onshore windfarm in respect of the natural heritage. Policy Statement No.02/02. Scottish Natural Heritage, Edinburgh, UK

SNH, 2013. A handbook on environmental impact assessment. Guidance for Competent Authorities, Consultees and others involved in the Environmental Impact Assessment Process in Scotland. Scottish Natural Heritage, Edinburgh, UK.

SNH, 2014. Guidance. Recommended bird survey methods to inform impact assessment of onshore windfarms. Scottish Natural Heritage, Edinburgh, UK

Simberloff, D., 1998. Flagships, umbrellas, and keystones: is single-species management passé in the landscape era?. Biological conservation, 83(3), p.247-257, DOI: 10.1016/S0006-3207(97)00081-5.

Slocombe D.S. 1998. Lessons from experience with ecosystem-based management. Landscape and Urban Planning, 40(1-3), p. 31-39, DOI: 10.1016/S0169-2046(97)00096-0.

Thompson, S., Treweek, J.R. and Thurling, D.J., 1997. The Ecological Component of Environmental Impact Assessment: A Critical Review of British Environmental Statements. Journal of Environmental Planning and Management, 40(2), p.157-171, DOI: 10.1080/09640569712164.

Warren, C. R. and Birnie, R. V., 2009. Re-powering Scotland: Wind Farms and the 'Energy or Environment?’ Debate. Scottish Geographical Journal, 125, p. 97-126. DOI:10.1080/14702540802712502

Waylen, K. A., Hastings, E. J., Banks, E. A., Holstead, K. L., Irvine, R. J. and Blackstock, K. L., 2014. The Need to Disentangle Key Concepts from Ecosystem-Approach Jargon. Conservation Biology, 28, p.1215-1224. DOI:10.1111/cobi.12331

Whitfiled, S., Reed, M., Thomson, K., Christie, M., Stringer, L.C. and Quinn, Q., 2011. Managing Peatland Ecosystem Services: Current UK Policy and Future Challenges in a Changing World. Scottish Geographical Journal, 127, p. 209-230. DOI:10.1080/14702541.2011.616864

Zawadzka, J.E., Corstanje, R., Fookes, J., Nichols, J., and Harris, J. 2017. Operationalizing the ecosystems approach: Assessing the environmental impact of major infrastructure development, Ecological Indicators, 78, p. 75-84, DOI: 10.1016/j.ecolind.2017.03.005. 